\title{
Dhoopan: Therapeutics of Herbal Fumigation in Ayurvedic texts
}

\author{
Bharat Chouragade ${ }^{1}$
}

${ }^{1}$ Professor-Head, Samhita Siddhant, Principal, Sri Sai Institute of Ayurvedic Medicine and Research, Bhopal, India

*Corresponding. Email: bharatmgac@gmail.com

https://doi.org/10.36018/ijyr.v4i1.69

\begin{abstract}
Herbal fume inhalation is a therapeutic module mentioned in detail in Ayurvedic literature for therapeutic purposes. Different herbal fume inhalation varieties are mentioned in Ayurvedic texts i.e. DhoomNasya (herbal fumes inhaled through the nose), Dhompana (herbal fumes taken through the nose or the mouth and exhaled through the mouth) and Dhoopan (treatment using herbal fumes in total). The present manuscript studied the selected portions of Ayurvedic texts to understand the various therapeutic purposes of Dhoopan described in Ayurveda. All classical Ayurvedic texts mentioned some form of herbal fume inhalation for therapeutics. For example for disease treatment, for health prevention, for mental illness, for fever, for child growth, for diseases of ears, eyes, teeth, etc. Besides therapeutics, dhoopan is also helpful for environmental benefits such as killing bugs, purifying the environment, etc. The study gives perspective and argues ways to identify components mentioned in the Ayurvedic formula especially where some non-herbal meanings were derived from the classic Sanskrit texts; hence opening-up a new dimension of research required for reviving the ancient methods given in Ayurvedic texts.
\end{abstract}

Keywords. Dhoopan, Herbal Fume Therapy, Ayurvedic Texts, Dhoompana, Dhoomnasya, Herbs

\section{Introduction}

Ayurveda is a traditional Indian therapeutic system. Its origin is believed to be from Vedic times. Infact, some scholars believed it as part of Atharveda (Upang) Sushrut Sanhita 1/1/5 says Ayurveda is Upand of Atharva veda [1]. Ayurveda mentions various herbal preparations and therapeutic modules for therapeutic purposes for example, oleation therapy (sneha vidhi), sudation therapy (sveda vidhi), emesis and purgation therapies (vamana and virecana vidhi), enema therapies (basti vidhi), nasal medication (nasya vidhi), inhalation of smoke (dhumapana vidhi), surgical treatment (sastrakarma vidhi), thermal cautery therapy (agnikarma vidhi) and so on. Decoction (Kwath), churna, vati, dhoopan, etc are some of the common forms of dosages (2).

Herbal fume inhalation is a therapeutic module mentioned in detail in Ayurvedic literature for therapeutic purposes. Different herbal fume inhalation varieties are mentioned in Ayurvedic texts i.e. Dhoom-Nasya (herbal fumes inhaled through the nose), Dhompana (herbal fumes taken through the nose or the mouth and exhaled through the mouth) and Dhoopan (treatment using herbal fumes in total). These are similar terms with some differences in method and purpose having common points of the utilization of herbal fume intake (2$3)$. 
Ashtanga Samagra of Vagbhatta described that nose is the door of the head for all treatments related to the head (नासा हि शिरसो द्वारम् तेन तद् व्याव्य हन्ति तान् II अ.ह.सू २०/१) (nasa hi shirso dvaram ten tad vyavy hanti taan.) (2). Administration of any form of medicine through the nose is called nasya (औषधम् औषध सिद्धं स्नेहो वा नासिकाभ्यां दीयते इति नस्यम। 40/21) (aushadham aushadh sidham sneho va nasikabhyam diyate iti nasyam.) (4). Herbal fumes given through the nose are also called dhoom nasya (2).

The term dhoompana made up of two words dhoom means mist/ vapour/smoke (here it refers to fumes of medicinal plants) and pana means to drink. Thus it can be defined as drinking the fumes of medicinal plants. In the process of dhoomapana the inhalation of fumes should be done with either the mouth or the nose but exhalation should be from the mouth only (5). The purpose of the Dhoompana as per the ayurvedic scholars is to detoxify, rejuvenate and empower the foundational elements, centers and organs along with perception, mind, and the entire physique. It also works as a preventative for psychological disorder and seasonal outbreaks and is prescribed in various diseases (5).

Dhoopan is a broad and common term and it refers to herbal fume application for disease treatment through inhalation as well as being in its presence. Kasyap Sanhita dedicated a separate chapter on various types of dhoopan purpose, preparation and utilization procedure in detail. The present manuscript studied the selected portions of Ayurvedic texts to understand the various therapeutic purposes of Dhoopan described.

\section{Dhoopan for health benefit as per Kashyap Samhita}

Kashyap Samhita (काश्यपसंहिता) has a separate chapter on Dhoopan, which is dhoopkalp adhyay (धूपकल्प अध्याय:), from which some selected details of Dhoopan for Health benefits made of different Dhoopan Dravya for various diseases are described below. Kashyap Samhita, dhoopkalp adhyay (काश्यपसंहिता धूपकल्प अध्यायः) (3)

\begin{tabular}{|c|c|c|}
\hline $\begin{array}{l}\text { Dhoopan Health } \\
\text { Purposes }\end{array}$ & Sanskrit & English \\
\hline $\begin{array}{l}\text { रोगनाशना: } \\
\text { (For disease } \\
\text { treatment) }\end{array}$ & $\begin{array}{l}\text { सिद्धार्थाश्चेति धूपास्ते चत्वारिंशदुदाह्नताः । } \\
\text { भिषक्सिद्धिकरा नृणां पुत्रदा रोगनाशनाः ।। } \\
\text { (sidharthashcheti } \quad \text { dhupaste } \\
\text { chatvarinshduhahratah. bhishksiddhikra } \\
\text { nranaam putrada rognashanah.) }\end{array}$ & $\begin{array}{l}\text { It implies that there is } 40 \text { dhoop with definite results. They provide } \\
\text { complete treatment, total health (capacity to produce progeny), and } \\
\text { disease free state. }\end{array}$ \\
\hline
\end{tabular}

\begin{tabular}{|c|c|c|}
\hline $\begin{array}{l}\text { सर्वभूतरुजापह: } \\
\text { (Destroying all } \\
\text { diseases) }\end{array}$ & $\begin{array}{l}\text { धृताक्षतं जातिपुष्पं मधु सिद्धार्थका वचा । गणधूप } \\
\text { इतिख्यातः सर्वभूतरुजापह: ।। } \\
\text { (Grutakshtam jatipushpam madhu } \\
\text { siddharthka vacha. Gandhoop itikhyataah } \\
\text { sarbhutrujapahah.) }\end{array}$ & $\begin{array}{l}\text { It is implied that clarified butter (ghee), rice (Oryza sativa), the flower } \\
\text { of jasmine (Jasminum sambac), honey, white mustard (Brassica } \\
\text { alba), and sweet-flag (Acorus calamus) make Gan-Dhoop which } \\
\text { destroys all kinds of diseases (Bhoot Rog). }\end{array}$ \\
\hline $\begin{array}{l}\text { ध्पोअयमरिष्ठम } \\
\text { (Destroys all } \\
\text { diseases } \\
\text { immediately) }\end{array}$ & $\begin{array}{l}\text { घृतं निम्बस्य पत्राणि मुल पुष्पं फलं त्वचम् । अरिष्टो } \\
\text { नाम धुपोडयमरीष्टं कुरुते क्षणात् ।I } \\
\text { (grutam nimbasya patrani mool pushpam } \\
\text { phalam tvacham. arishto naam } \\
\text { dhoopoayammarishtam kurute kshanat.) }\end{array}$ & $\begin{array}{l}\text { It implies that clarified butter (ghee), and five parts (Leaves, roots, } \\
\text { flowers, fruits and tree bark) of Neem (Azadirachta indica) make } \\
\text { Arishta-Dhoop which gives disease-free-state to the patient } \\
\text { immediately. }\end{array}$ \\
\hline
\end{tabular}


घृतं च पद्मकोशीरं बालकं केसरं रसम् । प्रतिधूप सर्वरोगेषु शम्यते (Treats diseases)
इति ख्यातः सर्वरोगेषु श्मते ।।

(grutam cha padmkoshiram balakam kesaram rasam. pratidhoop iti khyatah sarvarogeshu shmyate.)
It implies that clarified butter (ghee), blue lotus (पदमक padmak) (Nymphaea nouchali var), vetiver (Khas) (Chrysopogon zizanioides) (khas), netravala (Pavonia odorata) (नेत्रवाला), Naagkesar (Mesua ferrea), and Sarjras (Vateria Indica) makes Prati-dhoop which is effective in treating all diseases.
सुखावहः

(Health tonic)
घृतं श्वदंष्ट्रा वसुका हरिद्रे परिपेलवम् । वचा भार्गी च धूपोऽयं प्रतिधुपः सुखावहः ।।

(grutam kshvdanshta vasuka haridre paripelavam. vacha bhargi cha dhoopoayam pratidhoopah sukhavahah.)

It implies that clarified butter (ghee), gaukhuru (Tribulus terrestris),

Malabar nut flower (Justicia adhatoda (वसुक, बकपुष्प), turmeric, Daruhaldi (Berberis aristata) (दारुहल्दी), Coco-grass (Cyperus Rotundus) (परिपेलव), sweet-flag (Acorus calamus) (वच) and Glory flower (Clerodendron Serratum) (भारंगी) make a dhoop which is healthy.

घृतं स्थौणेयकं मांसी तगरं परिपेलवम् ॥ ह्रीवेरं शतपुष्पां च हरितालं मनःशिलाम्। मुस्तं हरेणुकामेलां धूपार्थमुपकल्पयेत् ।I शिशुको नाम धुपोऽयं सर्वरोगग्रहापहः । धूपने चानुधूपे च प्रतिधूपे च भार्गव

सर्वरोगग्रहाप्रह:

(Destroys all (grutam sthyoneyakam mansi tagarm diseases) paripelavam. hriveram shatpushpam cha haritaalam manah shilaam. mustam harenukamelaam dhooparthmupakalpayet. shishuko naam dhoopoyam sarveroggrahapahah. dhoopane chanudhupe cha pratidhope cha bhargav)
It implies that clarified butter (ghee), sthauneyak (स्थौणेयक) Jatamansi (Nardostachys jatamansi) (जटामांसी), Tagar (Valeriana wallichii) (तगर), coco-grass (Cyperus Rotundus) (परिपेलव), Hauber (Juniperus Communis) (हाऊबेर), fennel (Foeniculum vulgare) (सौफ), Hartal (Terminalia chebula) (हरताल), Sulphide of arsenic (manashila) (मनःशिला), Cypritol (Cyperus scariosus) (नागरमोथा), vitex seeds (Vitex agnus-castu) (हरेणुबीज) and green cardamomum (Elettaria cardamomum) (छोटीइलाइची) makes shishuk-dhoop which destroys all diseases and mental illness (गृह).

It implies that extract of resin of the longleaf pine tree (Pinus longifolia) (श्रीवेष्टक), Laksha (Laccifer lacca) (लाक्षा), Himalayan wild cherry (Padmaka) (Prunus cerasoides) (पद्मक), sandalwood (Indian sandalwood)(चन्दन), devdar (Cedrus deodara)(देवदारु), holy basil (Ocimum tenuiflorum) (तुलसी) and shal (शाल) - makes Varun-dhhop which should be used in the treatment of shakuni (शकुनी), pundrik (पुंडरीक), revati (रेवती) and shlaemishk (श्लैष्मिक) diseases in summer season.

It implies that clarified butter (Ghee), Raal (राल), suranjan (Colchicum luteum) (कृष्ण), marking nut tree (Semecarpus anacardium) (भिलावा), benzoin (Styrax benzoin) (शिलेयक), Haridra (Curcuma longa) (हरिद्रा), daruhaldi (Berberis aristata) (दारुहल्दी), Lac (लाक्षा), vetiner (Chrysopogon zizanioides) (खस), mustard (Brassica juncea)(सरसों), flower of holy basil (Ocimum sanctum) (तुलसी), vidang (Embelia ribes)(विडंग), jasmine (Crepe jasmine) (तगर), tejpatra (Cinnamomum tamala) (तेजपत्र), sweet-flag (Acorus calamus) (वच), asafoetida (Ferula asafoetida) (हिंग), netrabala (Pavonia odorata) (नेत्रवाला) makes kumar-dhoop which is promoter for Child growth.

It implies that clarified butter (ghee), white mustard (Sinapis alba) (सफ़ेदसरसों), costus (Dolomiaea costus) (कुठ), marking nut tree (Semecarpus anacardium) (भिलावा), sweet-flag (Acorus calamus) (वच), bastlomani (बस्तलोमानि), jasmine (Crepe jasmine) (तगर), himalayan birch (Betula utilis) (भोजपत्र), and Indian myrrh (Commiphora wightii) (गूगल) makes dashang-dhoop which is useful in all kinds of disease especially mental illness and epilepsy.
सर्वरोगेषु अपस्मार

विशेषण

(Treats diseases especially epilepsy)

al sidharthka shvetah kus bhallatakam vacha. bastlomani tagaram bhrjavartam saguggulu. dashango naam dhoopoyam prayojyah sarvrogishu. apasmare vesheshan graheshupgraheshu cha.)

Table 1. Purposes of Dhoopan for health benefits as per Kashyap Samhita (काश्यपसंहिता धूपकल्प अध्यायः). 


\section{Dhoopan for health benefit as per Charak and Sushrut Samhita}

Charak Samhita (6) and Sushrut Samhita (4) also describe use of dhoopan for various health benefits and therapeutic purposes. Some selected references for various disease treatments using dhoopan which are mentioned in these classic ayurvedic texts are given in table 2 .

\begin{tabular}{|c|c|}
\hline Dhoopan Health Purposes & Sanskrit and English \\
\hline $\begin{array}{l}\text { For epilepsy (अपस्मार) } \\
\text { treatment } \\
\text { चरक संहिता चिकित्सास्थानम } \\
\text { अपस्मार चिकित्साध्याय: श्लोक } 36 \\
\text { (charak samhita, chikitsa } \\
\text { sthanam, apasmara-chikitsa } \\
\text { adhyayah, shloka 36) }\end{array}$ & $\begin{array}{l}\text { पलङ्कषावचापथ्यावृश्चिकाल्यर्कसर्षपै: । जटिलापूतनाकेशीनाकुलीहिड्गुचोरकै: । । } \\
\text { लशुनातिरसाचित्राकुष्टैविड्भिश्च पक्षिणाम् । मांसाशिनाम् यथालाभम् बस्तमूत्रे चतुर्गुणे । । } \\
\text { सिद्धमभ्यन्जनं तैलमपस्मारविनाशनं । एतैश्चैवौषधै: कार्य धूपनं सप्रलेपनम् । । } \\
\text { (palnkshavchapathyavrushchikalyakesarshpaeah. jatilaputnakeshinakulihidnguchorkaeah. } \\
\text { lashunatirsachitrakushtaevidbhishch pakshinam. mansashinaam yathalaabhm bastmutre chaturgune } \\
\text { siddhmbhyanjnam taelmpasmarvinashanam. aytaeshchaevouahdhaeah karya dhoopnam sapralepnam.) } \\
\text { It implies that palpankshadi oil (पलङ्कषादि तेल) made of using guggal (Commiphora wightii) (गुग्गल), sweet } \\
\text { flag (Acorus calamus Linn.) (कडुवा वच), kernel of Chebulic Myrobalan (Terminalia chebula) (हरड), Kaknasa } \\
\text { (Martynia annua) (काकनासा), bark of Calotropis gigantea (मदार), mustard (Brassica juncea) (सरसो), } \\
\text { spikenard (Nardostachys jatamansı) (जटामासी), bermuda grass (Cynodon dactylon) (दूर्वा), nakuli (Rauvolfia } \\
\text { serpentina) (नाकुली), asafoetida (Ferula asafoetida) (हिंग), black jack (Bidens pilosa) (चोरपुष्पी), garlic (Allium } \\
\text { sativum) (लहसुन), asparagus (Asparagus racemosus) (अतिरसा), ceylon leadwort root (Plumbago zeylanica) } \\
\text { (चित्रा), indian costus (Saussurea Lappa) (कुठ), and mashaminam (मांसाशिना), by boiling them in oil to make } \\
\text { kalk followed by mixing with cooked mustard oil made with } 4 \text { times of bastmutre (बस्तमुत्रे). Massage this to } \\
\text { treat epilepsy. To treat epilepsy also dhoopan made of using these herbs (Indian bdellium-tree (Commiphora } \\
\text { wightii) (गग्गल) and others shall also be given along with massage of the former preparation. }\end{array}$ \\
\hline
\end{tabular}

For Fever treatment

(चरक संहिता चिकित्सास्थानम ज्वरचिकित्साध्याय: श्लोक 176 (charak samhita, chikitsa sthanam, jwarchikitsaadhyayah, shloka 176)

For treating eye disorder (सुश्रुतसंहिता उत्तरतन्त्रम अध्याय: 18 श्लोक 11 (sushruta samhita uttara tantram, adhyayah 18 shloka 11)
धूपनाग्जनयोगैश्च यान्ति जीर्णज्वरा: शमम् ॥ त्वड्ंमात्रशेषा येषां च भवत्यागन्तुरन्वयः । (dhoopnaanjnyogaeshch yanti jirnjwaraah shamam. tvdnmatrashesha yesham cha bhavtyagnturnvayah.)

It implies the details of Dhoopan for fever management. Chronic fever which is only felt on skin and Agantuk fever get cured by this dhoop of chronic fever and ointment.
For treating ear disorder

सुश्रुतसंहिता उत्तरतन्त्रम अध्याय: 22 श्लोक 53 (sushruta samhita uttara tantram adhyayah 22, shloka 53)

\section{स्विन्नेन यवपिष्टेन, स्नेहवीर्येरितं ततः ।}

यथास्वं धमपानेन कफमस्य विशोधयेत् । ।

(svinnena yavpishten, snehviryeritam tath yathasvam dhoompanen kaphmasya vishodhyet.) It implies that for the treatment of eye disease use a ball of softened barley is recommended and the kapha generated through this treatment shall be removed by shirovirechana (cleansing process) and dhoompan.
गुग्गुलो: कर्णदौर्गन्ध्ये धूपनं श्रेष्टमुच्यते ।
छर्दनं धमपानग्ज कवलस्य च धारणम् ।।

oopanam sheshtamuchyate. chhardanam dhoompaangja kavalasya cha dharnam.)

It implies various procedures to treat ear disorders along with dhoopan. For ear disorders dhoopan of guggul (Indian bdellium-tree, Commiphora wightii, गुग्गुल) is recommended as the best option. Apart from it, vaman, dhoompan, and gargle are also considered as prime options.

Table 2. Purposes of Dhoopan for health benefits as per Charak and Sushrut Samhita 


\section{Dhoopan for health benefit as per Bhaishajya ratnavali and Yogratnakar}

Other Ayurvedic texts Bhaishajya ratnavali

(भैषज्यरत्नावली) (7) and Yogratnakar (योगरत्नाकर) (8) also describe dhoopan (herbal fume inhalation) for various therapeutic purposes.

\begin{tabular}{|c|c|}
\hline For treating Mania & $\begin{array}{l}\text { सर्पि: पानादिनाssगन्तौ मन्त्रादिश्चेष्यते विधिः । } \\
\text { पूजाबल्युपहारेष्टिहोममन्त्रान्जानादिभिः ।। } \\
\text { जयेदागन्तुमुन्मादं यथाविधि शुचिर्भिषक् ।। }\end{array}$ \\
\hline & $\begin{array}{l}\text { (sarpih panadinagantou mantradish cheshyatevidhi. poojabalyupahareshti homamantragjdibhiah. } \\
\text { jayedagntumunmadam yathavidhi shuchirbhishk.) }\end{array}$ \\
\hline $\begin{array}{l}\text { 'पुराणधृत प्रयोग' अंतर्गत) (bhaishajya } \\
\text { ratnavali } \quad \text { unmadrogadhikarah, } \\
\text { 'puranghrut prayog' antargat) }\end{array}$ & $\begin{array}{l}\text { It implies that at the time of insanity (possession/obsession) (आगन्तुक उन्माद), use of mantra-tantra, } \\
\text { worshiping God, bali (a type of offering), offerings, yagya, japa (mantra chanting), hawan, and ointment } \\
\text { and nasya application, shall be performed by Ayurvedic practitioner after proper purification of self. This } \\
\text { way, it treats the insanity (आगन्तुक उन्माद). }\end{array}$ \\
\hline \multirow{2}{*}{$\begin{array}{l}\text { For treating various mental disorder } \\
\text { and fever }\end{array}$} & $\begin{array}{l}\text { कार्पासास्थिमयूरपिच्छबृहतीनिर्माल्यपिण्डीतकै - } \\
\text { स्त्वग्वांशीवृषदंशविट्तुषवचाकेशाहिनिर्मोककैः । } \\
\text { गोश्र्ट्गद्विपदन्तहिङ्गुमरिचैस्तुल्यैस्तु धूपः कृतः - } \\
\text { स्कन्दोन्मादपिशाचराक्षससुरावेशज्वरह्नः स्मृतः ।। } \\
\text { (karpa sasthi mayur pichchh bruhati nirmalya pinditkae-stvagvanshi vrushdansh vittu } \\
\text { hvachakeshahinirmokkaeah.goshrungdvipdant hing marichae stulyaestu dhoopah krutah } \\
\text { sandonmaadpishacharaksa suravesh jwarghanah smrutah.) }\end{array}$ \\
\hline & It implies that take equal parts of cotton (Gossypium hirsutum) (कपास) seeds, mayurpichchh (मयूरपिच्छ), \\
\hline \multirow{6}{*}{$\begin{array}{l}\text { (भैषज्यरत्नावली उन्मादरोगाधिकारः } \\
\text { 'पुराणधृत प्रयोग' अंतर्गत) (bhaishajya } \\
\text { ratnavali unmadrogadhikarah, } \\
\text { 'puranghrut prayog' antargat) }\end{array}$} & all five parts (flower, fruit, bark, leaves, and root) of african egg plant (Solanum indicum) (बृहती), \\
\hline & $\begin{array}{l}\text { Śivanirmālya (शिव निर्माल्य), black pulm (syzygium cumini) (मदनफल), vetiver (Chrysopogon zizanioides) } \\
\text { (खस), Bamboo manna (Bambusa bambos (L.) Voss) (वंशलोचन), orchid tree (Bauhinia variegata) (विडाल) }\end{array}$ \\
\hline & $\begin{array}{l}\text { (9), rice bran, sweet flag (Acorus calamus Linn.) (वच), jatamansi (Nardostachys jatamansi) (जटामांसी), } \\
\text { nirmok (निर्मोक), gum-Arabic tree (Acacia arabica - Bot.) (गोश्रृङ्ग) (9), Indian rose chestnut (Mesua }\end{array}$ \\
\hline & $\begin{array}{l}\text { Roxburghii) (द्विपदन्त) (9), Asafoetida (Ferula assa-foetida) (हिंग), Black pepper (Piper nigrum) (मारिच). } \\
\text { Using them, prepare a jaukut (coarse) powder and offer small quantities periodically to smokeless fire } \\
\text { which will treat various mental illnesses (skandapsmar (स्कन्दापस्मार) [type of epilepsy], pishachonmad }\end{array}$ \\
\hline & (पिशाचोन्माद) [type of mania], rakshasonmaad (राक्षसोन्माद) [type of mania] and devadesh unmad (देवावेश \\
\hline & न्माद) [type of mania] and fever. \\
\hline
\end{tabular}

काकुभकुसुमविडङ्गं लाङ्गलिभल्लातकं तथोशीरम् । श्रीवेष्टकसर्जरसं चन्दनमथ कुष्ठमष्टमं दघात् ।। एष सुगन्धो धूपः सकृत्कृमीणां विनाशकः प्रोक्तः। शय्यासु मत्कुणानां शिरसि च गात्रेषु यूकानाम् ।।

For Killing bugs (खट्मल, यूका, लीख)

(kakubha kusum vidang laanglibhllatakah tathoshiram. kshriveshtk sarjrasam chandanmath kushthamshtamam daghat. ash sugandho dhoopah sakrutkruninam vinashakah proktah. shayayaasu matkunaam shirsi cha gatreshu yukanaam.)

योगरत्नाकरः कृमिचिकित्सा श्लोक 10-11 (yoga ratnakarah krimi chikitsa shloka 10-11)
It implies that to prepare kriminashak-dhoop (bugs killing dhoop)- Make dhoop using powder of following eight herbs - flowers of arjun (Terminalia arjuna) (अर्जुन), vaaybhirang (Embelia ribes) (वायभिरंग), pure poison of Flame lily (Gloriosa superba) (करियारी), pure marking nut tree (Semecarpus anacardium) (भिलावा), vetiver (Chrysopogon zizanioides) (खस), Frankincense (लोहवान), raal (राल), Indian sandalwood (श्वेत चन्दन), costus (Saussurea Lappa) (कुठ). This dhoop shall kill worms-bugs (क्रीमी) at once. This dhoop can also be used to destroy bedbugs, nit and head lice.
For treating teeth infections

(योगरत्नाकरः कृमिचिकित्सा श्लोक 12 (yoga ratnakarah krimi chikitsa, shloka 12)
विशालाया: फलं पक्कं तप्तलोहे परिक्षिपेत् । तद्धूमो दन्तलग्नप्शेत्कीटानां पातनः परः ।। (vishalayah phalam pakkam taptlohe parikshipet. taddhumo dant lagnpshchetkitanam patnah parah.) It implies that vishala dhoop i.e. fumes of ripe colocynth (Citrullus colocynthis) (इन्द्रायण) produced by subjecting it to red hot iron results in treatment of tooth worms.

Table 3. Purposes of Dhoopan for health benefits as per Bhaishajya ratnavali and Yogratnakar. 


\section{Discussion and conclusion}

Ayurved is the science and wisdom of life. Dhoopan Chikitsa (herbal fume inhalation therapy) is an integral part of the Ayurvedic therapeutic system which has not been paid much attention in modern Ayurvedic treatments. All the Ayurvedic texts (Table 1-3) mentioned herbal fume inhalation (Dhumapana, dhoom nasya and dhoopan) for various diseases treatments; the raw material preparation and utility for all of these varieties of use of herbal fumes are more or less similar (Table $1-3)$.

While researching for the present study, the author came across the translation of some components of the sloka mentioned in the present manuscript by the translator, which was non-herbal in the nature. They are as given in Table 4.

\begin{tabular}{lll}
\hline Component of sloka & $\begin{array}{l}\text { The translation given in } \\
\text { the book }\end{array}$ & Potential meaning or comment \\
\hline $\begin{array}{l}\text { Bastlomani } \\
\text { (बस्तलोमानि) } \\
\text { (Table 1) }\end{array}$ & Hair Of Goat & $\begin{array}{l}\text { In Sanskrit the term loma (लोमा) stands for dendrite (heir like structure of plant), and } \\
\text { basti (बस्ती) stand for basti plant; hence bastlomani (बस्तलोमानि) could mean here } \\
\text { as dendrites of plant bast. }\end{array}$ \\
\hline $\begin{array}{l}\text { Mashaminam } \\
\text { (मांसाशिनां) (Table 2) }\end{array}$ & $\begin{array}{l}\text { Tongue Of The } \\
\text { Carnivorous Bird }\end{array}$ & $\begin{array}{l}\text { If the translation of mashaminam (मांसाशिनां) is taken as the tongue of the } \\
\text { carnivorous birds, then why is the specific carnivorous bird's name not mentioned } \\
\text { in sloka? - it may generate errors in the efficiency of the said formula. Hence, } \\
\text { mashaminam (मांसाशिनां) could mean another meaning in the present text. }\end{array}$ \\
\hline
\end{tabular}

\begin{tabular}{|c|c|c|}
\hline $\begin{array}{l}\text { Bastmutre (बस्तमुत्रे) } \\
\text { (Table 2) }\end{array}$ & Urine Of Goat & $\begin{array}{l}\text { Bast (बस्त) is the Sanskrit name of } 4 \text { plants while the term mutre (मूत्र) in Sanskrit is } \\
\text { also used for wine (fermentation). Thus it may be a fermented dosage of the plant } \\
\text { bast. }\end{array}$ \\
\hline $\begin{array}{l}\text { Mayurpichchh } \\
\text { (मयूरपिच्छ) }\end{array}$ & Feather Of Peacock & --- \\
\hline nirmok (निर्मोक) & Snake Skin & --- \\
\hline $\begin{array}{l}\text { Vidal (विडाल) (Table } \\
\text { 3) }\end{array}$ & Faeces Of Animal Vidal & $\begin{array}{l}\text { In terms of plant faeces, plants excreted products are like gum. Vidal in the sanskrit } \\
\text { dictionary (9) is the orchid tree (Bauhinia variegata), hence it could mean here the } \\
\text { gum of the orchid tree }\end{array}$ \\
\hline $\begin{array}{l}\text { Gaushring (गोश्रृङ्ग) } \\
\text { (Table 3) }\end{array}$ & Cow's Horn & $\begin{array}{l}\text { In the Sanskrit dictionary (9) the meaning of gaushring (गोश्रृङ्ग) is gum-Arabic tree } \\
\text { (Acacia arabica) }\end{array}$ \\
\hline $\begin{array}{l}\text { Dvipdant (द्विपदन्त) } \\
\text { (Table 3) }\end{array}$ & Ivory (Elephant Teeth) & $\begin{array}{l}\text { In the Sanskrit dictionary (9) the meaning of dvip (द्विप) is Indian rose chestnut } \\
\text { (Mesua Roxburghii) and dant (दन्त) is the seed. Hence, Dvipdant (द्विपदन्त) could } \\
\text { mean seed of Indian rose chestnut. }\end{array}$ \\
\hline
\end{tabular}

Table 4. Potential identification of the components of the sloka given Ayurvedic texts as herbs compared to non-herbal derivatives by the literal translation.

The author of the present manuscript disagrees with the translations performed by translators of the Ayurvedic Sanskrit texts for above-mentioned components of the formula from Table 1-3 and presented potential meanings in the Table 4 . The logic behind these components (Table 4) to be herbal in nature is given as below.
1) Different derivatives in Sanskrit: In the formula of Mahadhoop (Table 3), the translation of Dvipdant (द्विपदन्त) in the book is given as elephant teeth (Ivory). Ivory is a very strong bone (2-3 Mohs hardness) and is a non-inflammable substance. In addition the derivative given in the Table 4 is a seed of Indian rose chestnut plant. and 
(Elephant Teeth). Hence, it looks more logical that the creator of the sloka in sanskrit might have meant a plant.

2) Material Preparation: In addition, if Dvipdant (द्विपदन्त) in the book has been taken as elephant teeth (Ivory), then such hard material would be very tough to make Jaukut (coarse powder) and which would require high end machines. Such important information is not given in the Ayurvedic texts. So the process for the preparation of non-herbal components should also be given in texts. Hence, it is more likely that these non-herbal components are some types of herbs for which identification in today's time is required.

3) Sequence of herbs: Moreover, in the formula for example in the Mahadhoop, in the 16 components, there are only 4 [(Mayurpichchh (मयूरपिच्छ), Vidal (विडाल) Gaushring (गोश्रृड्ग), Dvipdant (द्विपदन्त)] nonherbal components, which are randomly incorporated. Hence, for the original creator of this sloka, it would had been more logical to mention non-herbal components separately from the herbalcomponents. However, there was no distinction made. Hence, it looked like these kinds of components might be herbal in nature.

4) Intuition knowledge, geographical availability and nomenclature:

a) There is a legend that Maharshi Charak had obtained the divine knowledge of herbs through establishing conscious connection with plants. Hence, the Rishi would be hesitant to use any component in the formula that would harm the animal. Some scholars believe that the Rishi might had mentioned using things of dead animals. However, timely obtaining things from dead animals before they decay is more impractical. Hence, it looked more likely that they were plants with names given as per their property or appearance to identify them easily in those days.

b) Meanwhile, obtaining snake skin from the jungle, elephant teeth from deep forest, or owl faeces from mountain areas, and the tongues of carnivorous birds from different places, etc, would be very impractical to obtain those components. It looked like considering storage, accessibility and geographical availability they were of plant origin.

c) In addition, in sanskrit names can not be literally translated; Some of the plants already have names that can not be literally translated for example Balak Netravala if translated is Child with eyes but it is a plant netravala (Pavonia odorata). Rather they should be contextually derived indicating potential for further research.

Dhoopan for therapy (herbal fume inhalation therapy) (dhoopan chikitsa) is a very efficient therapy. Modern literature and recent studies on herbal fume inhalation through Yagya (hawan) also support the potential of dhoopan chikitsa. In this therapy volatile phytoconstituent or the active bioactive molecules present in the form of herbal fumes are in vaporized or in sublimated state which are effective due to efficient entry through pulmonary route (10) indicating therapeutics potential of dhoopan. 


\section{References}

1. Vishwakarma H. Atharva Chikitsa Vigyan. Chaukhamba Krishnadas Academy, Varanasi, 1984. Page no 3.

2. Astanga Samgraha of Vagbhata. Nasyavidhi Adhyaya, Page 525. Chaukhamba Orientalia, Varanasi, ninth edition 2005.

3. Kashyapa Samhita. Dhoop kalpa adhyay (धूपकल्प अध्यायः). Chaukhamba Sanskrit Sansthan, Varanasi. Version Reprint Vikram Samvat 2063.

4. Sushruta Samhita. Part II (Uttaratantra). Chaukhamba Sanskrit Sansthan, Varanasi. Version 30, Vikram Samvat 2057

5. Rajurkar S, , Sethiya, P., Dhargalkar, N., Dilip, \& Gadgil. Ascertaining Classical Approaches of Ayurvedic 'DHUMPAN' for Health and Healing. Int J Pharmacogn ChineseMed. 2019,3(3):000171. Available from https://www.semanticscholar.org/paper/AscertainingClassical-Approaches-of-Ayurvedic-for-RajurkarSethiya/e38d5bbfd4175c11ac0293c3230d8240b3d1a6f4

6. Charaka Samhita. 'Vidyotini' Hindi commentaries ('विद्योतिनी' हिंदीव्याख़्योपेत्ता). Chaukhamba Orientalia, Varanasi-221001, Edition 40.
7. Bhaishajya Ratnavali. Shri Govinddassen written, 'Siddhiprada' - Hindi translation (श्रीगोविन्ददाससेनविरचिता, 'सिद्धिप्रदा' - हिंदीव्याख़्योपेत्ता). Chaukhamba Surbharti Publications, Varanasi, Edition, 2007.

8. Yogaratnakara:. 'Vidyotini' with Hindi commentaries ('विद्योतिनी' हिंदी टिका सहित:). Chaukhamba Sanskrit Sansthan, Varanasi. Version VII, Vikram Samvat 2058

9. Sri Chidambaram Narayanaswami and Klaus Glashoff. Sanskrit dictionary (website). Cochin, India, 2005. https://www.learnsanskrit.cc/

10. Joshi Rr, Raghuvanshi M, Pandya P. Yagyopathy Versus Oral And Iv Drug Administration: Evaluation For Pulmonary Tuberculosis Using Compartment Modeling. J Biol Syst. 2006;14(03):463-89. https://doi.org/10.1142/S0218339006001891 